\title{
Divorce Rate in the Slovak Republic as a Social and Educational Problem
}

\author{
Katarína Cimprichová Gežová *
}

\begin{abstract}
Divorce is considered an unwanted phenomenon in the society, although the divorce rate increases. There are many problems for both sides - parents and their children - coming along with divorce. The legal adjustment of divorce may violently strike not only the lives of children influenced by divorce but also the lives of other persons, whose existence is seriously endangered or complicated by establishing new life conditions. Family break-up and the loss of one parent leaves lifelong consequences on the child. The decision for divorce should be therefore thoroughly considered, because it is the point, where the source of loss of personal and family safety arises. Our aim is to point out the problems arising from divorce not only for the divorcing couple, but also for their children, above all, because divorce should not mean hostility for sensible people, particularly if they have children. It is necessary to find a way how to talk together before and during divorce and to do best in solving problems in the possibly shortest time.
\end{abstract}

Key words: marriage, family, crisis, divorce, children.

\section{Introduction}

In every family it comes to an argument or a conflict between partners. The institute of divorce is nothing bad as such, (often redemption), because it solves such problems that are not solvable by any other interventions. Divorce as such is not to blame for negative attendant circumstances in family. The process of divorce as such is not guilty for increasing the divorce rate, but the disagreement determinants which have reached it. The fact that partners want to solve their problems by divorce is in the process of divorce mostly the reason to separate marriage. On the other hand, every particular divorce situation is individual. "Fragments" of breaking-up hit always different people and complicate their lives in various ways. This terminal state of "dying out" of the family will never have ideal legal, official or economic tools to get rid of negative attendant features. Divorce can be regarded as a type of measurement that should prevent total emotional exhaustion, suffering and get rid of stress impulses caused by

Katarína Cimprichová Gežová, University of Matej Bel, Faculty of Education, Banská Bystrica, Slovakia; katarina.gezova@umb.sk 


\section{Acta Technologica Dubnicae \\ volume 6, 2016, issue 2}

long-term difficulties and disharmony in common life. It comes to massive changes in individuals' lives. It concerns the process of divorce as such, property division, agreement about further parental laws and duties, alimony for children or former partner. It's crucially important to cope with these issues quickly, although the rapid sequence of events does not offer too much space for it. It comes to the formation of a demanding situation getting the psyche of an individual into a not easy situation. Psychologists classify divorce as being on the second place regarding the seriousness and complexity of the situation immediately after the death of a close person (Poupětová, 2009, p. 18). The perception of divorce changed considerably after 1989. That year was a year of many significant changes from political as well as from economic and social points of view. The centralized and planned-controlled state adopted suddenly the system of market economics in autumn 1989. It brought two insights into praxis. On one hand, people gained new freedom in decision making, on the other hand, individuals became fully responsible for themselves. Obligation of work and fixed financial income changed after the revolution into survival from one day to another and fright of the future. Nowadays, the situation in the society causes not only existential problems, but it has a negative impact on new families. In many cases it comes to breakup and destabilization within the family what suppresses the resolution of young people to establish their own families. From the sociological point of view, the topic of divorce and its still increasing rate is not a taboo anymore. The ratio of divorced marriages to filled divorce petitions is for our little Slovakia still extremely high. Seriousness and consequences of divorce have been trivialized, what is obvious. The presented issue is addressed by recognized world authors, such as Alba-Fisch (2016), Demby (2016), Altmaier and Maloney (2007), Horn, Puffer, Roesch and Lehmann (2016), Jenkins, McGowan, Knafo and Noam (2016), Vanassche, Corijn, Matthijs and Swicegood (2015), Sodermans, Botterman, Havermans and Matthijs (2015), Tach and Eads (2015) and others. According to Višňovský (2010, p. 33), it comes to a decrease of the value of marriage and the value of family. The social status of women has changed and it is reflected in the structure of family relationships and the stability of traditional relationships in marriages.

\section{Discussion}

There's no doubt that divorce belongs to situations which are difficult to cope with, are full of conflicts and new obstacles which are needed to be beaten. Such an unpleasant situation may cause alcohol abuse, medicament addiction or development of different types of substantial or non-substantial addictions. It can strike both parents and children, because they consider similar situations an escape from stress. They build defense mechanisms subconsciously to cope with trauma. "Among most frequent defense mechanisms are the following: 


\section{Acta Technologica Dubnicae \\ volume 6, 2016, issue 2}

- rationalization - partners want to give generally accepted reasons for their action,

- projection - partners try to project their own mistakes into their partner's behavior and to get rid of the responsibility for family breakup" (Wolf, 1994, p. 72).

The precursors of divorce and its first, pre-divorce phase, are the problems between partners, commonly named as marital developing crisis. There are three marital crises, whereas the first one is obvious immediately after the first signs of communication problems and a decrease of sexual desire appears. The married couple cannot come to an agreement on basic things that did not use to be a problem before. Suddenly, things they have never noticed before become annoying, the partners are not able to get on well anymore, to ignore some of their needs and one of the partners becomes more egoistic than in the past. They have several arguments in a short period of time, but if they hear the word "divorce", they get scared and do everything to rescue their relationship. The beginning of this phase appears in the third to seventh year of marriage (Plzák, 1998, p. 119-123). The length of time between arguments and reconciliation shortens.

Consequently, the second marital developing crisis comes. It appears between the seventeenth and the twenty-fifth year of marriage. It can take one or more years. According to J. Prevendárová a G. Kubíčková (1996, p. 58), this crisis is connected with the coming retirement of partners and with the fright of future. Among other factors are health problems, higher sensitivity, feelings of lonesomeness and uselessness when children leave their homes - the so-called empty nest syndrome; that all can be the cause of a sudden wave of disagreements in partnership.

The third crisis comes due to deepening and not solving the problems of the previous stage. It starts in the fiftieth or the sixtieth year of partners' age. In addition to the feelings of uselessness, hormonal changes can occur. People need more energy to handle situations. Contrary to it, if the symptoms of third crisis get stronger, they cause higher nervosity and thick atmosphere in the household. The stronger signs of marital breakup are as they follow:

- indifference of one of the partners towards helping in the household;

- arguments concerning mostly finances;

- ventilation of problems outside the family;

- waning care of children;

- absence of sexual life;

- one of the partners is considering divorce (Lazarová, 2002, p. 63). 


\section{Acta Technologica Dubnicae \\ volume 6, 2016, issue 2}

It is important not to cease with communication with the partner during the crisis, although it often happens that an argument develops from an attempt to talk about problems rationally. In many experts' opinion, such a way of communication is useful as constructive arguments leading to a univocal solution are a good incentive to a new period of partnership coexistence. It is important to keep thinking positive, to have clear opinions and not to act in affect during the marital crisis. In our inquiry, we dedicated ourselves to the ways of remedy of broken partnerships and $48,57 \%$ of people said that they had tried to talk with their partner constructively, they had proposed a solution and they had wanted to solve the situation actively. We find this number quite low, because, in our opinion, not all the marital problems are so serious that the marriage should end up in divorce. We think that most of them are resolvable by means of communication or with the help of an expert. According to J. Prevendárová (2014, p. 35), the disability to come to an agreement springs from gender differences between men and women. The way of men's communication is often plain, general and sometimes more vulgar than women's. Men often make judgments and use imperatives. Men often relegate the listener to a subordinate position. Women use different relationship contexts, show their feelings, expect emotional support and want to have suggestive questions answered. Their expected result of an argument is that their partner admits that it is them who want the best for both of them.

People get married with expectations. They look for support from their partners, existential support in their families, sense of life and they try to escape from problems. When their marriage gets to a blind alley, they thus look back on their fulfilled or non-fulfilled existential desires. In the process of making the decision to fill in a divorce petition, the list of pros and cons of the marriage play a role. But to what extent do they assess the marriage? It brings about many further questions: What are the criteria for deciding whether the marriage is good or bad, whether it fulfils its function or not? In which way does this marriage fulfil its functions better or worse than other marriages? Will divorce give or take something from the family members? What is then the "reality" in marriage and after divorce? Wouldn't the couple be shocked after revealing the relativism of their perception of reality? Would they ask, "Does our marriage fulfil its purpose?", "Does it bring pros to our family members?", "Does the social environment accept the state of our marriage?", "Are the negative aspects of our marriage serious, unbearable?", "Would a break-up, respectively a new partner, compensate me or my children for the negatives of my present marital life?", instead of asking, "How is our marriage? Good? Bad? Better than other ones?"

Divorce is, however, the only socially accepted form of ending a marriage during the life of the partners. It is not only the affair of the couple and their children, but also a social affair influencing the social system. Ending a marriage 


\section{Acta Technologica Dubnicae \\ volume 6, 2016, issue 2}

is regulated by the Law about Family No. 36/2005 of the Collection of Laws, which tells, that "the court may end the marriage by divorce on the proposal of one of the partners if the relationship between the partners is as seriously disrupted and permanently broken-up, that the marriage cannot fulfil its purpose anymore and it cannot be presumed that partners renew their marital coexistence". The court finds out the causes having issued in serious relationship disrupt and it takes them into account during the process. The court always takes the interests of infants into consideration" (Act No. 36/2005 Coll. on family and on amendment of some other acts).

According to M. Hargašová (1983, p. 23) the causes of marriage breakup are connected in a complicated tangle of factors that have an impact on each other:

- biological (age uniqueness, temperament);

- psychological (characteristic features, skills, creativity);

- cultural-sociological (social norms, persistent opinions about family duties);

- physical (environment, economical and politic situation).

J. Gabura (1987, p. 7) lists the causes of breakup as follows:

- different education of partners;

- communication gap between the partners in the married couple that finally leads to an emotional breakup;

- change of value orientation in nowadays society;

- immature attitude of partners towards divorce;

- inability to solve small problems;

- another partner;

- improper expectations from the partner;

- personality traits;

- emotional absence

- romantic love;

- coexistence with a risky partner.

The Statistical Office of the Slovak Republic records as the most frequent cause of marriage breakup the divergence of characters, opinions and interests in total number of 6875 cases in 2013, what is about 921 less than in 2006, when this cause was recorded in 7796 cases. It is surprising, because the question, why would such partners get married if their characters were compatible with the relationship arises. Why did they get married if they had totally different opinions and interests? In 2013, infidelity is given as the second most frequent cause of breakup in 1149 cases and the third cause is alcoholism in 815 cases. We can claim that we have reached similar results in our search, too, although we anticipated some changes. We were convinced that if partners decide to get 


\section{Acta Technologica Dubnicae \\ volume 6, 2016, issue 2}

married, they know each other well and they are able to help each other to manage everyday situations. Unfortunately, men and women have often fixed ideas regarding their partners. It is necessary to take into consideration that there is no ideal partner and a right choice depends on the ability to adapt to the partner, to be tolerant and to make compromises. Our inquiry confirms the results by the Statistical Office but with one difference, infidelity of one of the partners, claimed by $46 \%$ of interviewees, takes the first place. The second reason was the divergence of characters, opinions and interests and the third one was alcoholism. We assume that the real cause of breakup lies in the divergence of characters but the married couples do not admit it in front of the court.

Marriage breakup hits the emotional life of partners, their financial independence or the question of housing that is firmly connected with finances. If the finances are concerned, $76.35 \%$ of women declared a definite worsening of their financial situation. The number of divorces had a slightly decreasing tendency in 2013 (according to the Statistical Office, 11637 marriages were divorced that year) contrary to 2006 when there came to a massive increase in the divorce rate in total number of 14007 marriages, so there were 49 divorces to 100 new marriages. Divorce has thus become a serious issue not only for a married couple getting divorced, their families, but also a problem of the whole society. It is a serious social and sociological problem. Several experts say that divorce has a huge impact on children's education and their further life in an incomplete family. Often, the school results get worse. The school - family cooperation is extremely important in general, but also in the field of prevention of socio-pathological phenomena. It is inevitable when dealing with problems in pupils' behavior (Emmerová, 2015, p. 116). Most children in the Slovak Republic are consigned to their mothers (the inquiry confirms $72.30 \%$ ). The author I. Špaňhelová (2010, p. 132) lists the following advantages for children:

- the child is under a more united education of one parent (the other parent has almost no opportunity to intervene in upbringing as rarely comes into contact with the child);

- the child lives in one stable environment - at home, only visits the other parent's household at weekends;

- fully accepts one parental role (it can have pros and cons, too, because this role is often overloaded).

However, Špaňhelová (2010, p. 132) points out the disadvantages of being under the exclusive custody of the mother which can have a negative impact on the child: 


\section{Acta Technologica Dubnicae \\ volume 6, 2016, issue 2}

- children do not know much about the role of the other parent - the male or father's role (they do not know about their interests, attitudes to certain situations, etc.);

- children do not know how their fathers behave in everyday situations;

- mothers' behaviour can be perceived as stressful (since they must take care of themselves and their households);

- it can seem that mothers do not have enough time for them because of their busyness;

- mothers' busyness does not allow them to talk with their children peacefully;

- mothers often find themselves in a stressful situation because of the lack of finances. They cannot let their children have what they would like to have.

In the given case, fathers do not have the opportunity to take a big part in the education of their children, because they spend only a short period of time together, mostly every second weekend. In most developed countries, alternating custody is a legally regulated solution after the divorce of parents. It was passed by the amendment of the Act on Family from 1 July 2010 in Slovakia as well. The civic association Fathers' League has published an overview of foreign studies about the advantages of alternating custody on its website www.ligaotcov.sk. After summarising 33 inquiries including totally 1846 children under the custody of one of the parents (mother or father) and 814 children in serial (alternating) custody, compared with children in complete families, it follows that children in alternating custody have significantly better conditions for socializing than children being under the custody of one of the parents (mostly the mother). In our research, we realized the absence of researches dealing with the preference of alternating custody. We were surprised by its results, because alternating custody took place before the exclusive custody of the father, indeed in $26.13 \%$. This type of custody is not common in our society. There are many supporters and opponents of alternating custody. Špaňhelová (2010, p. 139) speaks about the propriety of alternating custody regarding the age of children, "The introduction of alternating custody is recommended for children from the third year of age, whereas children under this age need to live in a stable environment. In such an environment they gain the feeling of safety and then they can change the environment, as well". Men demand alternating custody more often than women, what springs from prejudices in our society. Women strictly insist on the exclusive custody of mothers. We can state that the aim of alternating custody is, above all, to preserve and to strengthen an equal contact of an infant with both parents. "Alternating custody can work very well under the condition that both parents are mature and flexible personalities, able of mutual communication, parents and children incline to such type of custody and the households of the parents are close to each other. A failure or an absolute disability of alternating custody 


\section{Acta Technologica Dubnicae \\ volume 6, 2016, issue 2}

comes about when there is a strong enmity between parents, if they are not able to communicate without unceasing arguments, if one parent has a serious objection against such a custody and their households are too distant from each other" (Warshak, 1996, p. 172). It is very important for parents to cooperate and to consider what is best for their children. "By bringing up and self-education it is necessary to point out the adaptation functions providing the environment with a balance and the balance of human organism. Personality is formed in the process of the mutual interaction between the human and the environment. All the external conditions form an individual, but the relationships between people have a decisive influence on this formation" (Perhács \& Paška, 1995, p. 157).

\section{Conclusion}

People get married for various reasons; to find the sense of life, defence, shelter and they expect some positive effects. Contrary to it, if their partnership (marriage) ends up in failure - divorce, individuals can find themselves in an even worse subjective situation and position in the society than before getting married. Nowadays, the society develops hectically under the conditions of globalization, technical progress and social turnarounds. This factor influences young people's behaviour and decision-making to a great extent. Nowadays, when people get into the position of "homo homini lupus" (one a wolf to another), it is very important to lead the youth, to help them with their position in life, to clarify the significance of marriage and the importance of choosing a suitable partner to them, because a good marriage does not come from nothing, it is a dynamic, developing sensitive "social organism", the shape of which depends on the married couple and their behaviour to each other.

\section{References}

Alba-Fisch, M. (2016). Collaborative Divorce: An Effort to Reduce the Damage of Divorce. Journal of Clinical Psychology, 72(5), 444-457.

Altmaier, E., \& Maloney, R. (2007). An initial evaluation of a mindful parenting program. Journal of Clinical Psychology, 63(12), 1231-1238.

Demby, S. L. (2016). Parenting Coordination: Applying Clinical Thinking to the Management and Resolution of Post-Divorce Conflict. Journal of Clinical Psychology, 72(5), 458-468.

Emmerová, I. (2015). School Social Pedagogue in a Theoretical Reflection, Problems and Educational Needs of a School Social Pedagogue in the Slovak Republic. The New Educational Review, 41(3).

Gabura, J. (1987). Prevencia rozvodovosti mladých manželstiev. Bratislava: Živena. 


\section{Acta Technologica Dubnicae \\ volume 6, 2016, issue 2}

Gežová, K. (2012). Rozvod, porozvodová adaptácia a možnosti riešenia z hl'adiska sociálnej andragogiky a sociálnej pedagogiky. Banská Bystrica: PdF UMB.

Gruyová V. (2015). Rozvodovost' v Slovenskej republike ako spoločenský, sociálny a výchovný problem (Diploma thesis). Banská Bystrica: PdF UMB.

Hargašová, M. (1983). Rozvod - posledná možnost'. Nové slovo, 21(5).

Horn, R., Puffer, E. S., Roesch, E., \& Lehmann, H. (2016). 'I don't need an eye for an eye': Women's responses to intimate partner violence in Sierra Leone and Liberia. Global Public Health, 11(1-2), 108-121.

Jenkins, J. M., McGowan, P., Knafo-Noam, A. (2016). Parent -offspring transaction: Mechanisms and the value of within family designs. Hormones and Behavior, 77, 53-61.

Lazarová, M. (2002). Ako sa (ne) rozviest'. Bratislava: Semic Media.

Perhács, J., \& Paška, P. (1995). Dospelý človek v procese výchovy. Bratislava: Stimul.

Plzák, M. (1988). Poruchy manželského soužití. Praha: SPN.

Poupětová, Š. (2009). Netrapte se po rozvodu. Praha: Grada Publishing.

Prevendárová, J., \& Kubíčková, G. (1996). Základy rodinnej výchovy. Bratislava: Mladé letá.

Prevendárová, J. (2014). Rodinná terapia v praxi. Bratislava: Radost'.

Sodermans, A. K., Botterman, S., Havermans, N., \& Matthijs, K. (2015). Involved Fathers, Liberated Mothers? Joint Physical Custody and the Subjective Well-being of Divorced Parents. Social Indicators Research, 122(1), 257-277.

Špaňhelová, I. (2010). Ditě a rozvod rodičů. Praha: Grada Publishing.

Tach, L. M., \& Eads, A. (2015). Trends in the Economic Consequences of Marital and Cohabitation Dissolution in the United States. Demography, 52(2), 401-432.

Vanassche, S., Corijn, M., Matthijs, K., \& Swicegood, G. (2015). Repartnering and Childbearing After Divorce: Differences According to Parental Status and Custodial Arrangements. Population Research and Policy Review, 34(5), 761-784.

Višňovský, L. (2010). Transformácia spoločnosti na Slovensku a jej dopad na rozvodovost' v Banskobystrickom kraji. In L. Višňovský \& J. Hroncová et al., Slovenská rodina v kontexte transformačných premien. Banská Bystrica: PdF UMB.

Warshak, R. A. (1996). Revoluce v porozvodové péči o děti. Praha: Portál.

Wolf, D. (1994). Ked' odchádza partner. Ako sa vyrovnat' s rozchodom a rozvodom. Bratislava: Ikar.

Zákon o rodine 36/2005 Z. z.

http://www.ligaotcov.sk 